\title{
The Implications of Non Performing Loans on Nigerian Economic Growth (1992-2009).
}

\author{
Chude, Nkiru Patricia-Nezianya ${ }^{1}$ and Chude, Daniel Izuchukwu ${ }^{2}$ \\ ${ }^{1}$ Lecturer, Department Of Banking And Finance, Anambra State University, Igbariam Campus- Nigeria. \\ ${ }^{2}$ Lecturer, Department Of Accountancy, Anambra State University, Igbariam Campus- Nigeria.
}

\begin{abstract}
Traditionally, the ability of the financial subsector to play its role in reducing non-performing loan has been periodically punctuated by its vulnerability to systemic distress and macroeconomic volatility, and policy fine turning inevitability. The purpose of this project was to ascertain the implication of non-performing loan on economic growth in Nigeria. This study adopts quantitative technique in generating data and OLS in its analysis. A stationary test was carried out using the Augmented Dickey - Fulker test (ADF) and stationary test found at first difference at $1 \%$ and 5\% level of significance. The Johansen-guselius co-integration technique employed in this study proved to be superior in assessing the co-integrating properties of variables. The result of the test indicates if co integration equations at 5 percent level of significance. The study finds that there is a long run relationship between non-performing loan and economic growth in Nigeria and there is significant relationship between inflation rate and non-performing loans. We conclude that non-performing loan can induce or retard in order to minimize the effort non-performing loan o the economy as a whole and also avoids the encroachment of the factors responsible for non-performing loan into the banking system, the regulatory authorities may have to use better measures of evaluating the features of non-performing loan at an early stage. This will no doubt create sufficient lead-time to apply remediable solution before serious damage is done.
\end{abstract}

Keywords: Non-performing loan, macro-economic volatility, economic growth, co-integration, remediable solution.

\section{Introduction}

In Nigeria, the ability of the financial subsector to play its role has been periodically punctuated by its vulnerability to systemic distress and macro-economic volatility, and policy fine tuning inevitability. Consequently, the financial reforms were focused on further liberalization of banking business ensuring competition and safety of the system, and proactively positioning the industry to perform the role of intermediation and playing a catalytic role in economic development. In many emerging markets including Argentina, Brazil and Korea, the financial reforms has also become prominent as banks strive to become more competitive and resilient to shocks as well as reposition their operations to cope with the challenges of the increasing globalize banking system. Each continent except Africa (with possible exception of South Africa) has a fair share of Mega banks to support economic growth and development (Kama, 2006).

\section{The Concept Of Non Performing Loans In Nigeria}

There is no global standard to define non-performing loans at the practical level. Variations exist in terms of the classification system, the scope, the contents. Such problem potentially adds to disorder and uncertainty in the NPL issues. For instance, as described by Se-Hardk (2003).Credit risk management can be explained with simple meaning, individually and jointly. Credit can be defined as an amount of money that is given by a creditor and taken by a debtor that will be paid for at some future date, in return for benefits received earlier such as goods purchased or loan obtained (Coyle, 2005) during 1990s', there were three different methods of defining non-performing loans in Japan, the 1993 method based on banking laws, the Bank's selfvaluation in March 1996, and the Financial Revival Laws Based Debt Disclosure in 1999. These measurements have gradually broadened the scope and scales of the risk management method similar to the trend in Japan, more countries, regulators and banks are moving towards adopting and adapting better and more consensus practices. For example, in the U.S, federal regulated banks are required to use the fire-tier non-performing loan classification system according to BIS: Pass, Special Mention Substandard, Doubtful, and Loss. Presently, the fire-tier system is the most popular risk classification method, or in some cases, a dual system, of reporting according to their domestic policy guidelines as well as the fire-tier system.

\section{The Effects Of Non Performing Loans On The Growth Of Nigerian Economy}

Non-performing loans can lead to efficiency problem for banking sector. It is found by a number of economists that failing banks tend to be located far from the most efficient frontier Berger and Humphrey (1992), Barr and Siems (1994) De Young and Whalen (1994), Wheclock and Wilson (1994), because banks 
don't optimize their portfolio decisions by lending less than demanded what's more, that are evidences that even among banks that do not fail, there is a negative relationship between the non-performing loans and performance efficiency (Kwan and Eisenbeis (1994), Hughes and Moon (1995), Resti (1995)).

The phenomena that banks are reluctant to take new risks and commit new loans is described as the "credit crunch" problem. According to the United States Council of Economic Advisors (1991), credit crunch is a situation in which the supply of credit is restricted below the range usually identified of investment projects. A "credit crunch" is a disequilibrium phenomenon. It is present when banks are unwilling to lend, especially when a firm with profitable projects cannot obtain credit in spite of low interest rates (lower than the expected marginal products). Credit crunch results in excess demand for credit and hence credit rationing, where loans are allocated via non-price mechanism. Eventually, it imposes additional pressure on the performance of the monetary policy.

The idea of credit crunch has drawn attention when the traditional view failed to satisfactorily explain the economy state for those countries that suffered from the South-East Asian financial crisis in 1997. Under the traditional view, the link between the interest rate change and the real economic activity occurs through investment and consumer durable expenditure.

In response to the currency crisis in 1997, the interest rate was raised. It was strongly believed by IMF that the hike would help stabilize the foreign currency market and eventually induce banking reform by crowding out low-profit projects. However, the persistent fall in economic growth rate and the lasting economic recession cast doubt on the true benefits of the policy and the effectiveness of the traditional view of the transmission mechanism. The idea of credit crunch addresses an alternative explanation for the transmission mechanism.

During a crisis, in order to restore the credibility among creditors and depositors, failing financial institutions not only try to expand their equity bases, but also reduce their risk assets or change the composition of the asset portfolio. As a result of such defensive action, the corporate debtors are always targeted, thus standing the overall economic growth.

\section{The Establishment Of The Assets Management Corporation Of Nigeria (Amcon)}

As part of a broad banking sector crisis resolution strategy. The AMCON Act 2010 was signed into law on July 19, 2010. And invariably became operational in the same year, 2010. AMCON is an establishment owned by he Federal government of Nigeria managed through the Central Bank of Nigeria (CBN) and Federal Ministry of Finance. It is an implementing agency whose operational policies originate from the CBN and Federal Ministry of Finance (Nwokoji, 2011).

The company (AMCON) has the responsibility of absorbing the non-performing loans of the deposit money banks in the country. In broad terms, AMCON is established to assist eligible financial institutions to efficiently dispose of eligible bank assets, efficiently manage and dispose of eligible bank assets the best achievable financial returns on eligible bank assets or other assets acquired by it.

In accordance with above objectives, the company is to perform related functions such as, AMCON would serve as a vehicle to free the banks from the weight of their non-performing assets and accelerate the process of financial revitalization of the banking sector, acquiring eligible bank assets from eligible financial institutions, holding, managing, realizing and disposing of eligible bank assets including the collection of interest, principle and capital due and the taking over of collateral security such assets, and paying coupons on, and redeeming at maturity, bonds and debt securities issued by the corporation as consideration for acquisition of eligible bank assets.

\section{Capital Adequacy On Non-Performing Loans}

CBN (1995) claims that banks are expected to maintain adequate capital to meet their financial obligations operate profitably and contribute to promoting a sound financial system.

It is for these reasons that the $\mathrm{CBN}$ prescribes minimum capital requirements.

This minimum ratio of capital adequacy has been increased from 6 percent in 1992 to 8 percent in 1996. it is further stipulated that at least 50 percent of the component of a bank's capital shall comprise paid-up capital and reserves, while every bank shall maintain a ratio of not less than one to ten (1.10) between its adjusted capital funds and its total credit.

When a bank's capital falls below the prescribed ratio, it is an indication that the bank may be heading for distress.

Bank examination reports showed that a good number of banks operating in Nigeria were grossly under capitalized. This situation has been attributed to the low level of initial capital, the effect of inflation, the adverse operating results mainly due to tier inability to make appreciable recoveries from their non-performing assets and the large portfolio of non-performing loans maintained by some banks. These factors have combined to erode the capital base of many backs, with the introduction of prudential guidelines, banks were required to suspect interest due, but unpaid on classified assets and to make provisions for non-performing credit facilities, 
a good proportion of which was subject to losses. Inability to meet stipulated higher minimum capital requirements was one of the criteria used for classifying banks into either "healthy" or "unhealthy" and later category was barred from the foreign exchange market.

In describing capital inadequacy, Ogundina (1999) argues that capital in any business whether bank or company serves as means by which losses may be absorbed. It provides a cushion to withstand abnormal losses not covered by current earnings pattern. Unfortunately a good number of banks are grossly under capitalized. This situation could partly be attributed to the fact that many of the banks were established with very little capital. This problem of inadequate capital has been further worsened by the huge amount of non-performing loans which have eroded the capital base of some of these banks.

Available statistics on banks' capitalization reveal that as at the end of 1992, 120 operating banks in the country required the aggregate additional capital to the tune of N5.6 billion to meet statutory minimum capital funds set by bank regulators for 1992 .

\section{Model Specification}

In this study, the relationship between non-performing loan and Nigeria economy was measured by using the model specification of Levine (1993).

It was also used by Adebiyi (2004) who investigated linkage between interest rate policy and the financing of the Nigerian manufacturing sector.

This model therefore estimates that:

$\mathrm{Y}_{\mathrm{t}}=\mathrm{a}_{0}+\mathrm{a}_{1}+\mathrm{x}_{\mathrm{t}}+\mathrm{u}_{\mathrm{t}} \ldots(1)$

Equation (1) above is the growth equation

Where

$\mathrm{Y}_{\mathrm{t}}$ is the Non-Performing Loan (NPL)

$\mathrm{a}_{0}$ is the interest term

$a_{1}$ is the regression coefficient

$\mathrm{x}_{\mathrm{t}}$ is a set of baseline explanatory variable that have been shown to be robust determinants of non-performing loan and $\mathrm{u}_{\mathrm{t}}$ is the error term.

Model which specifies that the non-performing loan is significantly influence by the non performing loan measures or indicators. This is because we are interested in the answer about the most influential non performing loan variable, we estimate the Ordinary Loan Square (OLS) model including four popular measures of non-performing loan. We therefore re-specify the model above to capture the objective of our study.

The above model was modified and estimated as follows

NPL $=($ RGDP) INTRATE, SPI, INFL) $\ldots . .(2)$

i.e NPL $\mathrm{N}_{\mathrm{t}}=\mathrm{a}_{0}+\mathrm{a}_{1}$ INTRATE $_{\mathrm{t}}+\mathrm{a}_{2}+\mathrm{SPI}_{\mathrm{t}}+\mathrm{a}_{\mathrm{INF}}+\mathrm{u}_{\mathrm{t}} \ldots(3)$

Where

NPL $\quad=\quad$ Dependent Variables $(\mathrm{Yt})$

$\mathrm{X} \quad=\quad$ Independence Variables

INTRATE $\quad=\quad$ Interest Rate $(\mathrm{Xt})$

SPI $\quad=\quad$ Stock Price Indices $(\mathrm{Xt})$

INFL $\quad=\quad$ Inflation Rate $(\mathrm{Xt})$

$\mathrm{t} \quad=\quad$ Time Series (Annual)

$\mathrm{a}_{0} \quad=\quad$ Represents the constant or the intercept on $\mathrm{y}$ axis

$\mathrm{a}_{1} \ldots \mathrm{a}_{6} \quad=\quad$ Are the Regression Co-efficient

$\mathrm{U}_{\mathrm{t}} \quad=\quad$ Error or disturbance term

To determine the consistency of the impact of non-performing loan on Nigerian economy, lagged linear value of the variables will be include in the regression estimation of equation (2) above

\section{Data Analysis}

We shall analyse the time series characteristics of the chosen variables during the period 1992-2009 ADF unit root test were contented on all the variables

Unit Root test

The result of the ADF unit root in table 1.1 below shows that the following variables are stationary at first (ISF)

1. Real Gross Domestic Product

2. Interest Rate

3. Stock Price Indices

4. Inflation Rate.

The stationarity test was judged by the maximum eigenvalue at $5 \%$ and $10 \%$ critical values 
The Implications Of Non Performing Loans On Nigerian Economic Growth (1992-2009).

Table 1.1 ADF Unit Root Test for stationarity

\begin{tabular}{|l|l|l|l|l|l|}
\hline Variables & T. Statistics & Critical levels 1\% & $\mathbf{5 \%}$ & $\mathbf{1 0 \%}$ & Decision \\
\hline RGDP & -1.700 & -4.356 & -3.595 & -3.233 & $1(1)$ \\
INRATE & -1.799 & -4.356 & -3.595 & -3.233 \\
SPI & -2.267 & -4.374 & -3.603 & -3.238 \\
INFL & -3.0154 & -4.356 & -3.593 & -3.233 & $1(1)$ \\
\hline
\end{tabular}

NOTE: All variable stationary at first differencing

Co-integration Test

The Johansson co integration test was conducted on the selected variables. The results obtained from the above unit root test shows that all the variables are integrated of order one on the basis of the above unit-root tests results, we apply the co integration tests. The results are presented below.

Cointegration test results

\begin{tabular}{|l|l|l|l|l|}
\hline Hypotheses & Eigenvalue & T. statistic & 0.05 critical value & probability \\
\hline None $*$ & 0.923778 & 16.4698 & 95.75366 & 0.000 \\
At most $1 *$ & 0.805363 & 101.11171 & 69.81889 & 0.000 \\
At most 2* & 0.660859 & 60.20159 & 47.85613 & 0.0023 \\
At most 3* & 0.586713 & 33.18286 & 29.79707 & 0.0196 \\
At most 4* & 0.227212 & 11.09252 & 15.49471 & 0.2059 \\
\hline
\end{tabular}

* (*) denotes rejection of the hypothesis at $5 \%$ significance level.

The test indicates 4 cointegration equation (s) at 5\% significance level.

\section{Presentation of OLS results}

As a co integration relationship has been established among the variables than ordinary least square (OLS) model can be estimated to determine the dynamic behaviour of bank lending decision with respect to its determinants with the help of econometric view (e-view) package, the OLS is run and present below.

Table 3: Ordinary Least Square Estimates
\begin{tabular}{|l|l|l|l|}
\hline Variables & Coefficient & Standard Error & T. statistics \\
\hline D(NPL (-1) & 0.00333 & 0.002578 & 1.291780 \\
D(NPL (-2) & 0.52752 & 0.67463 & 0.082529 \\
CONSTANT & -123275.0 & 328525.0 & -0.37524 \\
RGDP & 0.171930 & 0.07988 & -2.15224 \\
INRATE & 0.690606 & 1461.99 & 4.886356 \\
SPI & -0.915380 & 0.735879 & 1.358919 \\
INFL & 0.823670 & 0.696578 & 0.189326 \\
\hline
\end{tabular}

R-squared

0.512980

Adj. R-squared $\quad-0.815576$

Sum Sq. resides $\quad 0.180029$

S.E equation

F-statistic

0.648210

Log likelihood

1.739274

Akaika AIC

Schwarz Sc

Mean dependent $\quad 0.227874$

S.D dependent $\quad 0.133609$

The ordinary least square mechanism was used for this exercise. The result indicates that real gross domestic product, interest rate and inflation have significant positive impact on non-performing loan. While stock price index have negative impacts on non-performing.

\section{Model Adequacy}

We have made use of the following parameters to ascertain the adequacy of our model

i. $\quad \mathrm{R}^{2}$ and adjusted $\mathrm{R}^{2}$

ii. Akaike and Schwarz information criteria

$\mathrm{R}^{2}$ and adjusted $\mathrm{R}^{2}$ : The $\mathrm{R}^{2}$ of the model is 0.512980 while the adjusted $\mathrm{R}^{2}$ is -0.815576 . Hence, $62176 \%$ of changes in NPL can be attributed to the selected variables.

Akaike and Schwarz: The value of -0.414539 and -0.17063 for the Akaike and Schwarz fall within the acceptable region of and therefore confirm the adequacy of the chosen model. This means that the variables forms a good fit for the model.

Test of Research Hypothesis

Ho: There is no significant relationship between banks non performing loan and inflation in Nigeria. 
Hi: There is significant relationship between banks non performing loan and inflation in Nigeria

\section{Statistics Test}

The test statistics are;

1. The size and sign of the co-efficient

2. The size of the t-statistic

\section{Level of significance}

The null hypothesis is rejected if the t-value of the arising coefficient of the variables is significant at $5 \%$ level.

\section{Hypotheses II}

Ho: $\quad$ There is no significant relationship between banks non performing loan Gross Domestic Product of Nigeria.

Hi: There is significant relationship between banks non performing loan Gross Domestic Product of Nigeria.

\section{Statistics Test}

The test statistics are;

1. The size and sign of the co-efficient

2. The size of the t-statistic

\section{Level of significance}

The estimation is adjusted to be significant or not at $5 \%$ level.

The Decision Rule:

The null hypothesis is rejected if the t-value of the arising coefficient of the variables is significant at 5\% level.

\section{Results}

As shown above, the variable real gross domestic product (RGDP) appeared in our ordinary least square (OLS) model estimate with a positive sign and significant coefficient.

Based on this factor, we therefore reject null hypotheses two and agree with alternative hypotheses that there is significant relationship between non performing loan and gross domestic product in Nigeria.

\section{Hypotheses III}

Ho: $\quad$ Non performing loan has no significant impact on interest rate growth.

Hi: Non performing loan has significant impact on interest rate growth.

\section{Statistics Test}

As in the case with the other hypotheses, the choice of test statistics here are;

1. The size and sign of the co-efficient for the large borrowing

2. The size of the t-statistics

The Decision Rule:

The null hypothesis is for the non significant relationship between interest rate and non performing loan. Of the $\mathrm{t}$-value statistics of its coefficient is significant at $5 \%$ level.

\section{Results}

The variable interest rate (INRATE) appeared with positive sign on our model.

This indicates a very significant coefficient of 0.690606 with t-statistics of 4.886356 and thus counters null hypotheses. Therefore, the null hypotheses are rejected with a conclusion that high interest rate has had significantly influence non performing loan.

The positive sign suggest the validity of a long run equilibrium relationship among the variables.

\section{Summary Of Research Findings}

Based on the analysis made after the data have been collected and presented in a logical and sequential manner, the following findings were made. Table 1.1 indicated that all variables are stationed at level and first differencing. Meaning that all the variable used are a good measure of bank lending decision. This has been proved statistically by the use of ordinary least square (OLS). The Johansson co-integration test was conducted on the selected variables. The results obtained from the above unit root test shows that all the variables are integrated of order one on the basis of the above unit-root tests results we apply the Johansson co-integration equation(s) at $5 \%$ significance level.

Based on the above analysis, three empirical results were found, test of hypotheses one indicates that the variables inflation (INFL) appeared in our ordinary least square estimate with a positive sign and significant coefficient. Based on this factor, we agree with alternative hypotheses that there is significant relationship between inflation and non performing loan.

Test of hypotheses two indicates that the variable real gross domestic product (RGSP) appeared in our ordinary least square estimate with a positive sign and significant coefficient. Based on this factor, we agree with alternative hypotheses that there is significant relationship between nonperforming loan and economic 
growth in Nigeria.

Test of hypotheses, three indicates that the variable interest rate (INRATE) appeared with positive sign. This indicates a very significant coefficient of 0.690606 and thus counters null hypotheses. Therefore, the null hypotheses are rejected with a conclusion that high interest rate had significantly influence non performing loan. The positive sign suggest the validity of a long run equilibrium relationship among the variables.

\section{Conclusion}

Based on the research findings, it is important to emphasize that the role of financial system was quantitatively important in the management of non performing loan to allow for economic growth in Nigeria. The empirical model is developed in the light of recent developments in the methodology of econometric modeling and analysis of time series with stochastic non-stationary components starting with an analysis of the unit root properties and ordinary least square (OLS) estimate of the relevant series.

The key problems set to be address on this study is to ascertain the level of significant that non performing loan has on the economic growth of the country.

This study set three objectives and achieve them. From the research findings, the study concluded that there is significant relationship between inflation and non performing loan, that there is significant relationship between non performing loan and economic growth in Nigeria, and high interest rate has had significantly influence non performing loan meaning that the more interest rate management, the more the level of economic growth in Nigeria.

Based on the analysis done in this study, we can conclude that non-performing loan can induce or retard growth depending on their qualities.

\section{Recommendations}

Based on the foregoing research findings and their respective implications, the following are recommended:

1. There is an urgent need for sound management of non-performing loan to achieve economic growth in Nigeria. This is necessary for its positive effect on the economic growth of the country.

2. This study also recommends that in order to minimize the effect non performing loan on the economy as a whole and also avoid the encroachment of the factors responsible for non-performing loan into the banking system, the regulatory authorities may have to use better measures of evaluating the features of nonperforming loan at an early stage. This will no doubt create sufficient lead-time to apply remediable solution before serious damage is done.

3. The banks must endeavour to develop maturity profile that can accommodate the matching of their assets and liabilities.

4. Every loan granted by each of the banks has to be adequately collateralized and the incidence of insider related credits must be deemphasized to avoid loan losses or huge non-performing loans.

5. The regulatory authorities on the other hand should engage themselves in capacity building to enable them perform their supervisory and regulatory functions as effectively as possible.

\section{References}

[1]. Adelma, A. (2009), A Note on the Theme of too many instruments, Oxford Bulletins of Economics and Statistics, 71(1): 4-58

[2]. Anaemeje, A.C (2007), Banking and Finance Professionalism in the $21^{\text {st }}$ Century and Beyond. The Nigerian Banker, Journal of the Chartered Institute of Bankers of Nigeria, October-December Edition, 14-17.

[3]. Anya, O. (2003): Corporate Governance as an Effective Tool for Combating Financial and Economic Crimes. The Nigerian Bankers, Journal of the Chartered Institute of Bankers of Nigeria, October-December Edition, 32-36.

[4]. Berger, A (1996) "Relationship Lending and Lines of Credit in Small Firm Finance; Journal of Business, 68(3); 23-30.

[5]. Bernake, B.S (1986); "Alternative Explanations of the Money Income Correlation" Carnegis Rochester Conference Series on Public Policy 25, 49-100.

[6]. Bernake, B.S (1989); “Agency costs, Net Worth and Business Fluctuations”, American Economic Review, 79(1) 14-31.

[7]. Capiro, J. (2005); "Starting Over Safely Rebuilding Banking System” World Bank.Org 14285.P.

[8]. Capiro, J. (1996); Bank Insolvencies; Cross Country Experience, World Bank Policy and Research Working Paper 1574 (Washington).

[9]. Freeman B. (1998): Environmental Ecology: The impacts of pollution and other stresses on ecosystem structure and function. United State of America, Academic Press, Inc.

[10]. Francis, M. (2007): Customer Relationship Management, Concepts and Tools Burlington M.A.

[11]. Gordon, W., Cheese J, Sherril K., \& Rushton A. (1984): Introducing Marketing by MCB University Press Ltd Bradford.

[12]. Grosse D.H and Hempel, E.A (1973), Management policies for commercial banks, New jersey, prentice Hall Inc; Englewood Cliffs. Central Bank of Nigeria, Annual Report and Account, various years.

[13]. Harrington, N. (1999): Risk Management and Insurance (4 ${ }^{\text {th }}$ edition) JohnWilly and son publication, New York Chichester Brishare-Toronto-Singapore.

[14]. Jhingan, M.L. (2002) Money, Banking International Trade and Public Finance, Vrinda Publication (p) Ltd 3-5 Ashish Complex Delhi-10091 John Willy and Son publication, New York. Chichester Brishare Toronto - Singapore.

[15]. Khan, S.A. (1994): The political Economy of oil, Oxford. Oxford University press. 